\title{
THE CONTROL OF PLASTID INHERITANCE IN PELARGONIUM. IV
}

\author{
R. A. E. TILNEY-BASSETT \\ Department of Genetics, University College of Swansea, Wales
}

Received 8.i.76

\begin{abstract}
SUMMARY
Thirty-six $\mathrm{G} \times \mathrm{W}$ crosses and $36 \mathrm{~W} \times \mathrm{G}$ crosses are made between six chimera cultivars, containing mutant white plastids in their germ layers, and the six green clones derived from them. The estimated outputs of green plastids and the percentages of variegated embryos are compared by the analysis of variance. The analysis confirms that changes in the pattern of extra-nuclear plastid inheritance are determined to a major extent by variations in the nuclear genotype of the female cultivar, even when the female contains the mutant plastids, and to a minor extent by changes in the nuclear genotype of the male. The behaviour of mutant plastids closely follows that of normal ones, except that the output of mutant plastids is never as great as for the corresponding green plastids either on the female or the male side. Owing to the effects of their different nuclear genotypes the six cultivars can be arranged in order of decreasing maternal strength as $\mathrm{MBC}>\mathrm{LG}>\mathrm{DV}>\mathrm{JCM}>\mathrm{FS}=\mathrm{FoS}$. Hence some nuclear genotypes permit a greater output of male than female plastids while others permit fewer male plastids and may even eliminate them altogether. It is suggested that the nuclear genes determine plastid inheritance by the selective control of plastid replication so that the output of plastids need have little resemblance to the input ratio.
\end{abstract}

\section{INTRODUGTION}

THE pattern of biparental plastid inheritance in zonal pelargoniums is largely determined by the nuclear genotype of the female parent, with the male, contributing plastids, but having only a minor influence on the controlling system (Tilney-Bassett, 1970b). Two cultivars have similar green plastids but distinctive nuclear genotypes. The cultivar green Dolly Varden has the ger otype $P r_{1} P r_{1}$ which determines the type I segregation pattern $(\mathrm{G}>\mathrm{V}>\mathrm{W})$ in which, after $\mathrm{G} \times \mathrm{W}$ plastid crosses, most offspring are green, rather less variegated and a few are white, or occasionally the variegated are more frequent than green. The second cultivar, green Flower of Spring, has the genotype $\operatorname{Pr}_{1} \operatorname{Pr}_{2}$ which determines the type II segregation pattern $(\mathrm{G}>\mathrm{V}<\mathrm{W})$ in which, after $\mathrm{G} \times \mathrm{W}$ plastid crosses, green and white offspring are approximately equally frequent and variegated generally fewer (TilneyBassett, 1973). The difference between the segregation patterns is determined by the female parent while still diploid before meiosis takes place (Tilney-Bassett, 1974b). The $\operatorname{Pr}$ gene is thought to control plastid inheritance by having some effect on plastid replication in the zygote. The more common homozygote tends to discourage the transmission of mutant plastids from the male parent, whereas with the less common heterozygote (TilneyBassett, 1974a) the mutant male plastids are transmitted as successfully as the normal female ones. It is tentatively suggested (Tilney-Bassett, 1974b) 
that $P r_{2}$ is the mutant allele and, when $P r_{2}$ is present, a controlling system that seeks to recognise and remove abnormal male plastids and plastid DNA in the zygote becomes largely ineffective, thereby permitting the very successful replication of the white plastids.

These developments in our understanding of the control of plastid inheritance in zonal pelargoniums are largely based on the intensive analysis of only two cultivars. It is therefore timely to discover how far the principles hold for other cultivars. In addition, the analysis is mostly based on the results of $\mathrm{G} \times \mathrm{W}$ plastid crosses. There is therefore a pressing need to see whether the same principles hold for the reciprocal $W \times G$ plastid crosses. This can be done, as alluded to in a recent review (Tilney-Bassett, 1975), by reciprocally crossing six different variegated cultivars by the six different isogenic green clones derived from them, to make a total of $36 \mathrm{G} \times \mathrm{W}$ and $36 \mathrm{~W} \times \mathrm{G}$ plastid crosses. It is the purpose of this paper to present the results of this extensive crossing programme.

\section{Materials AND methods}

As source of mutant white plastids (W), the cultivars used in the crossing programme are all white-over-green mesochimeras with the layer structure L I green, L II white, L III green. The six cultivars are cl. Foster's Seedling (FoS), cl. Flower of Spring (FS), cl. J. C. Mapping (JCM), cl. Dolly Varden (DV), cl. Lass O'Gowrie (LG) and cl. Miss Burdette-Coutts (MBC). On selfing, all produce white embryos as the germ cells are developed from the genetically white L II layer. As source of green plastids (G), isogenic bud variants are derived from each of the six chimera cultivars; in the case of FoS and JCM these have the layer structure G G W, and in the other four cultivars all three layers are green. On selfing, all six produce green embryos as the germ cells develop from the genetically green L II layer.

Pollinations within cultivars (FS G $\times$ W FS) are nuclear selfs, and between cultivars (FS G $\times$ W MBC) nuclear crosses. Yet, in regard to the plastids, both these nuclear selfs and crosses are plastid crosses. Plastid selfs $(\mathrm{DV} G \times \mathrm{G} D V$ or $\mathrm{DV} \mathrm{W} \times \mathrm{W} \mathrm{DV}$ ) are not discussed in the present experiments.

The estimation of the percentage green plastid contribution to the offspring for each cross is made as described previously (Tilney-Bassett, 1973). In order to conform with recent terminology used by other workers in the field of organelle genetics, this estimate is now described as the green plastid output; the white plastid output is 100 minus the green plastid output when expressed as a percentage. The classification of variegated and white embryos is changed slightly. In previous experiments, white embryos with green tips, indicating the presence of green chloroplasts in the suspensor cells, were classified as white in order to relate them as closely as possible to observations of germinating seedlings in which the suspensor would not be seen (Tilney-Bassett, 1970a). Consideration of their frequency patterns in a variety of crosses makes it seem likely that these are more accurately described as extreme forms of variegated embryo and in the present paper this change is made. A specific advantage of this modification is that it more clearly reveals those crosses in which there are few or no pure white embryos. 


\section{The analysis of plastid crosses}

The results of crossing the six cultivars with each other in the 36 combinations of $\mathrm{G} \times \mathrm{W}$ and 36 combinations of $\mathrm{W} \times \mathrm{G}$ plastid crosses are set out in table 1 . The segregation frequencies fully confirm the earlier finding, with more limited data (Tilney-Bassett, 1970b), that the proportions of green, variegated and white embryos, and the estimates for the percentage green plastid output, is relatively constant with the same female parent, that is the variation caused by six different males is quite small. This feature is just as true for crosses with a white female parent as for those with a green one. Hence the data fully substantiate the great importance of the female parent and the minor importance of the male.

When we compare the segregation pattern for the six different females after $\mathrm{G} \times \mathrm{W}$ crosses, they fall into two well-defined groups. As LG, MBC and DV all fall into the type I pattern, with a green plastid output of 69-99.8 per cent, it seems likely that they may have the same genotype, $\operatorname{Pr}_{1} \operatorname{Pr}_{1}$, as has been demonstrated for DV. Similarly, as FoS, FS and JCM all fall into the type II pattern, with a green plastid output of 45-64 per cent, it seems likely that they may have the same genotype, $\mathrm{Pr}_{1} \mathrm{Pr}_{2}$, as has been demonstrated for FS (Tilney-Bassett, 1973). The two groups remain distinct after $\mathrm{W} \times \mathrm{G}$ crosses when the type II plants have a high frequency of green embryos with a proportionately low frequency of variegated and white, whereas the type I plants are markedly shifted towards lower green and higher variegated and white frequencies. This difference is more easily expressed as a green plastid range of 79-99 per cent for type II plants compared with 28-76 per cent for type I plants. These results show that an important distinction between the two types is that the type II plants permit more male plastids to enter the embryos than do type I plants. Thus after $\mathrm{G} \times \mathrm{W}$ crosses, when male plastids are mutant, type II plants permit $36-55$ per cent male plastids, whereas type I plants permit only $1-31$ per cent. Likewise, after $\mathrm{W} \times \mathrm{G}$ crosses, when male plastids are normal, type II plants permit 79-99 per cent male plastids compared with $28-76$ per cent by type I plants. If we assume that the normal condition is to have more plastids entering via the female than via the male parent, as has been found directly in Oenothera by electronmicroscopy (Meyer and Stubbe, 1974), and indirectly by genetic analysis (Schötz, 1974, 1975), then the behaviour of the type I plants represents the normal condition, which is fully compatible with the type I cultivars being the more common (Tilney-Bassett, 1974a). On this basis it would seem that the type I plants are better at discriminating against the same male plastids than are the type II plants.

Superimposed on the difference between the two types is the differing behaviour of normal and mutant plastids. When a valid comparison is made, the crossing results show that the mutant plastids are never as successful as the normal. Thus in type I plants, when the mutant plastids are in the female, the mutant plastid transmission ranges from 24.9 to 71.9 per cent compared with 69.8 to 99.6 per cent for normal plastids. Similarly, in type II plants, when the mutant plastids are in the female, the mutant plastid transmission ranges from 1.8 to 30.9 per cent compared with 45.9 to 63.5 per cent for normal plastids. In the same manner normal plastids in the male are always more successful than mutant.

Within the two groups there is considerable variation both within and 


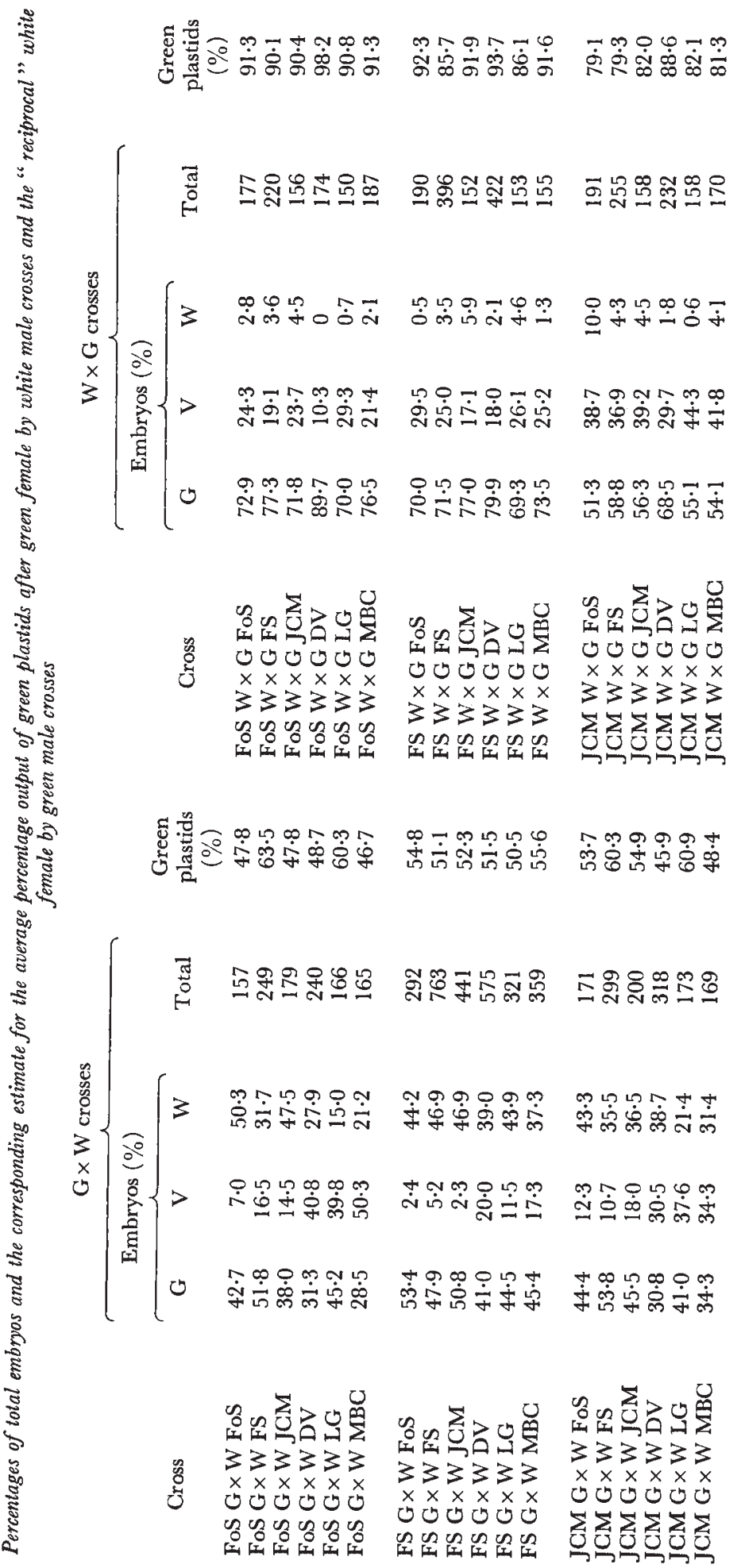




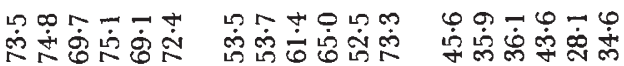

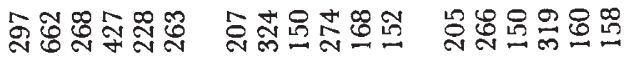

†ํ்

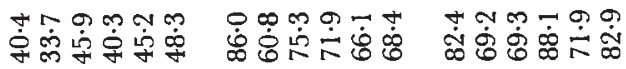

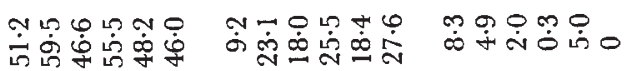

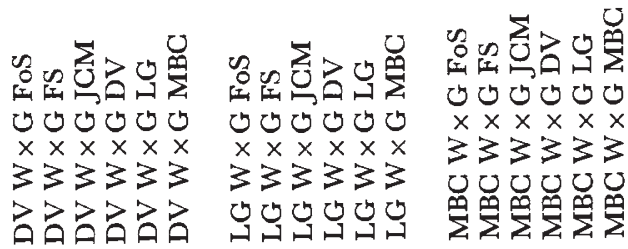

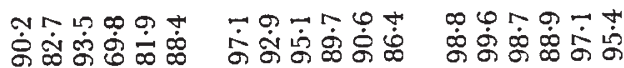

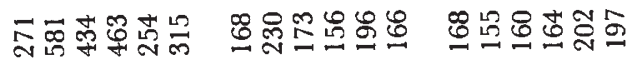

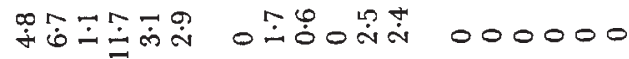

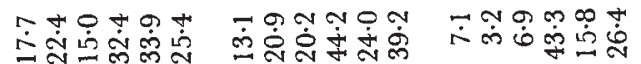

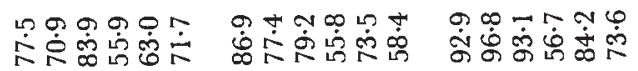

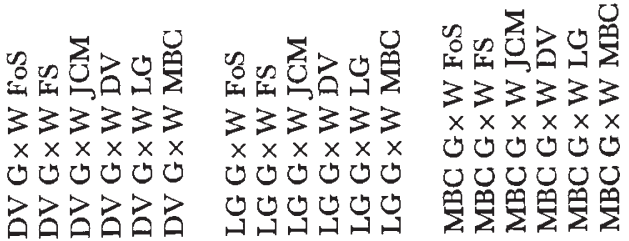


between cultivars, which might reflect underlying genotypic differences. The data are therefore examined more deeply by the analysis of variance-a method that has never previously been applied to the analysis of either chloroplast or mitochondrial genetic studies. The two parameters investigated are the percentage green plastid output and the percentage of variegated embryos. The relationship between them is variable. For the same green plastid contribution percentages of variegated embryos can be very far apart, similarly for the same percentage of variegated embryos it is possible

\section{TABle 2}

Layout for the analysis of variance showing the angular transformed data for the estimates of the percentage green plastid output (upper values) and for the percentages of variegated embryos (lower values), taken from the original data of table 1

(a) $G \times W$ crosses

\begin{tabular}{|c|c|c|c|c|c|c|c|}
\hline \multirow{2}{*}{$\begin{array}{l}\text { White } \\
\text { male } \\
\text { cultivars }\end{array}$} & \multicolumn{6}{|c|}{ Green female cultivars } & \multirow{2}{*}{$\begin{array}{l}\text { Row } \\
\text { totals }\end{array}$} \\
\hline & FoS & FS & JCM & DV & LG & MBC & \\
\hline FoS & $\begin{array}{l}43 \cdot 74 \\
15 \cdot 34\end{array}$ & $\begin{array}{r}47 \cdot 75 \\
8 \cdot 91\end{array}$ & $\begin{array}{l}47 \cdot 15 \\
20 \cdot 53\end{array}$ & $\begin{array}{l}71 \cdot 76 \\
24 \cdot 88\end{array}$ & $\begin{array}{l}80 \cdot 20 \\
21 \cdot 22\end{array}$ & $\begin{array}{l}83 \cdot 71 \\
15 \cdot 45\end{array}$ & $\begin{array}{l}374 \cdot 31 \\
106 \cdot 33\end{array}$ \\
\hline FS & $\begin{array}{l}52 \cdot 83 \\
23 \cdot 97\end{array}$ & $\begin{array}{l}45 \cdot 63 \\
13 \cdot 18\end{array}$ & $\begin{array}{l}50 \cdot 94 \\
19 \cdot 09\end{array}$ & $\begin{array}{l}65 \cdot 42 \\
28 \cdot 25\end{array}$ & $\begin{array}{l}74 \cdot 55 \\
27 \cdot 20\end{array}$ & $\begin{array}{l}86 \cdot 47 \\
10 \cdot 30\end{array}$ & $\begin{array}{l}375 \cdot 84 \\
121 \cdot 99\end{array}$ \\
\hline JCM & $\begin{array}{l}43 \cdot 74 \\
22 \cdot 38\end{array}$ & $\begin{array}{r}46 \cdot 32 \\
8 \cdot 72\end{array}$ & $\begin{array}{l}47 \cdot 81 \\
25 \cdot 10\end{array}$ & $\begin{array}{l}75 \cdot 23 \\
22 \cdot 79\end{array}$ & $\begin{array}{l}77 \cdot 21 \\
26 \cdot 71\end{array}$ & $\begin{array}{l}83 \cdot 58 \\
15 \cdot 23\end{array}$ & $\begin{array}{l}373 \cdot 89 \\
120 \cdot 93\end{array}$ \\
\hline DV & $\begin{array}{l}44 \cdot 26 \\
39 \cdot 70\end{array}$ & $\begin{array}{l}45 \cdot 86 \\
26 \cdot 57\end{array}$ & $\begin{array}{l}42 \cdot 65 \\
33 \cdot 52\end{array}$ & $\begin{array}{l}56 \cdot 66 \\
34 \cdot 70\end{array}$ & $\begin{array}{l}71 \cdot 28 \\
41 \cdot 67\end{array}$ & $\begin{array}{l}70 \cdot 45 \\
41 \cdot 15\end{array}$ & $\begin{array}{l}331 \cdot 16 \\
217 \cdot 31\end{array}$ \\
\hline LG & $\begin{array}{l}50 \cdot 94 \\
39 \cdot 11\end{array}$ & $\begin{array}{l}45 \cdot 29 \\
19 \cdot 91\end{array}$ & $\begin{array}{l}51 \cdot 30 \\
37 \cdot 82\end{array}$ & $\begin{array}{l}64 \cdot 82 \\
35 \cdot 61\end{array}$ & $\begin{array}{l}72 \cdot 15 \\
29 \cdot 33\end{array}$ & $\begin{array}{l}80 \cdot 28 \\
23 \cdot 42\end{array}$ & $\begin{array}{l}364 \cdot 78 \\
185 \cdot 20\end{array}$ \\
\hline $\mathrm{MBC}$ & $\begin{array}{l}43 \cdot 11 \\
45 \cdot 17\end{array}$ & $\begin{array}{l}48 \cdot 22 \\
24 \cdot 58\end{array}$ & $\begin{array}{l}44 \cdot 08 \\
35 \cdot 85\end{array}$ & $\begin{array}{l}70 \cdot 09 \\
30 \cdot 26\end{array}$ & $\begin{array}{l}68 \cdot 36 \\
38 \cdot 76\end{array}$ & $\begin{array}{l}77 \cdot 62 \\
30 \cdot 92\end{array}$ & $\begin{array}{l}351 \cdot 48 \\
205 \cdot 54\end{array}$ \\
\hline $\begin{array}{l}\text { Column } \\
\text { Totals }\end{array}$ & $\begin{array}{l}278 \cdot 62 \\
185 \cdot 67\end{array}$ & $\begin{array}{l}279 \cdot 07 \\
101 \cdot 87\end{array}$ & $\begin{array}{l}283 \cdot 93 \\
171 \cdot 91\end{array}$ & $\begin{array}{l}403 \cdot 98 \\
176 \cdot 49\end{array}$ & $\begin{array}{l}443 \cdot 75 \\
184 \cdot 89\end{array}$ & $\begin{array}{l}482 \cdot 11 \\
136 \cdot 47\end{array}$ & $\begin{array}{r}2171 \cdot 46 \\
957 \cdot 30\end{array}$ \\
\hline
\end{tabular}

(b) $W \times G$ crosses

\begin{tabular}{|c|c|c|c|c|c|c|c|}
\hline \multirow{2}{*}{$\begin{array}{c}\text { Green } \\
\text { male } \\
\text { cultivars }\end{array}$} & \multicolumn{6}{|c|}{ White female cultivars } & \multirow{2}{*}{$\begin{array}{l}\text { Row } \\
\text { totals }\end{array}$} \\
\hline & FoS & FS & JCM & DV & LG & $\mathrm{MBC}$ & \\
\hline FoS & $\begin{array}{l}72 \cdot 85 \\
29 \cdot 53\end{array}$ & $\begin{array}{l}73 \cdot 89 \\
32 \cdot 90\end{array}$ & $\begin{array}{l}62 \cdot 80 \\
38 \cdot 47\end{array}$ & $\begin{array}{l}59 \cdot 02 \\
39 \cdot 47\end{array}$ & $\begin{array}{l}47 \cdot 01 \\
68 \cdot 03\end{array}$ & $\begin{array}{l}42 \cdot 48 \\
65 \cdot 20\end{array}$ & $\begin{array}{l}358 \cdot 05 \\
273 \cdot 60\end{array}$ \\
\hline FS & $\begin{array}{l}71 \cdot 66 \\
25 \cdot 91\end{array}$ & $\begin{array}{l}67 \cdot 78 \\
30 \cdot 00\end{array}$ & $\begin{array}{l}62 \cdot 97 \\
37 \cdot 41\end{array}$ & $\begin{array}{l}59 \cdot 87 \\
35 \cdot 49\end{array}$ & $\begin{array}{l}47 \cdot 12 \\
51 \cdot 24\end{array}$ & $\begin{array}{l}36 \cdot 81 \\
56 \cdot 29\end{array}$ & $\begin{array}{l}346 \cdot 21 \\
236 \cdot 34\end{array}$ \\
\hline JCM & $\begin{array}{l}71 \cdot 95 \\
29 \cdot 13\end{array}$ & $\begin{array}{l}73 \cdot 46 \\
24 \cdot 43\end{array}$ & $\begin{array}{l}64 \cdot 90 \\
38 \cdot 76\end{array}$ & $\begin{array}{l}56 \cdot 63 \\
42 \cdot 65\end{array}$ & $\begin{array}{l}51 \cdot 59 \\
60 \cdot 20\end{array}$ & $\begin{array}{l}36 \cdot 93 \\
56 \cdot 35\end{array}$ & $\begin{array}{l}355 \cdot 46 \\
251 \cdot 52\end{array}$ \\
\hline DV & $\begin{array}{l}82 \cdot 29 \\
18 \cdot 72\end{array}$ & $\begin{array}{l}75 \cdot 46 \\
25 \cdot 10\end{array}$ & $\begin{array}{l}70 \cdot 31 \\
33 \cdot 02\end{array}$ & $\begin{array}{l}60 \cdot 07 \\
39 \cdot 41\end{array}$ & $\begin{array}{l}53 \cdot 76 \\
57 \cdot 99\end{array}$ & $\begin{array}{l}41 \cdot 32 \\
69 \cdot 82^{b}\end{array}$ & $\begin{array}{l}383 \cdot 21 \\
244 \cdot 06\end{array}$ \\
\hline LG & $\begin{array}{l}72 \cdot 34 \\
32 \cdot 77\end{array}$ & $\begin{array}{l}68 \cdot 11 \\
30 \cdot 72\end{array}$ & $\begin{array}{l}64 \cdot 97 \\
41 \cdot 73\end{array}$ & $\begin{array}{l}56 \cdot 26 \\
42 \cdot 25\end{array}$ & $\begin{array}{l}46 \cdot 43 \\
54 \cdot 39\end{array}$ & $\begin{array}{l}32 \cdot 01 \\
57 \cdot 99\end{array}$ & $\begin{array}{l}340 \cdot 12 \\
259 \cdot 85\end{array}$ \\
\hline $\mathrm{MBC}$ & $\begin{array}{l}72 \cdot 90 \\
27 \cdot 56\end{array}$ & $\begin{array}{l}73 \cdot 15 \\
30 \cdot 13\end{array}$ & $\begin{array}{l}64 \cdot 38 \\
40 \cdot 28\end{array}$ & $\begin{array}{l}58 \cdot 31 \\
44 \cdot 03\end{array}$ & $\begin{array}{l}58 \cdot 89^{a} \\
55 \cdot 80\end{array}$ & $\begin{array}{l}36 \cdot 06 \\
65 \cdot 57\end{array}$ & $\begin{array}{l}363 \cdot 69 \\
263 \cdot 37\end{array}$ \\
\hline $\begin{array}{l}\text { Column } \\
\text { Totals }\end{array}$ & $\begin{array}{l}443 \cdot 99 \\
163 \cdot 62\end{array}$ & $\begin{array}{l}431 \cdot 85 \\
173 \cdot 28\end{array}$ & $\begin{array}{l}390 \cdot 33 \\
229 \cdot 67\end{array}$ & $\begin{array}{l}350 \cdot 16 \\
243 \cdot 30\end{array}$ & $\begin{array}{l}304 \cdot 80 \\
347 \cdot 65\end{array}$ & $\begin{array}{l}225 \cdot 61 \\
371 \cdot 22\end{array}$ & $\begin{array}{l}2146 \cdot 74 \\
1528 \cdot 74\end{array}$ \\
\hline
\end{tabular}

Note: The values marked " a " and " b" are outliers; their calculated errors are over three standard deviations above the means. An estimated value for "a " is 48.73 and an estimated value for " $\mathrm{b}$ " is 55.98 . 
to find examples with a very different green plastid output. Yet it is also possible to seek out results where there is a significant correlation between percentages of variegated embryos and estimates for green plastids.

The model for the anovar is $H_{0}: Y_{i j}=\mu+\hat{o}_{i}+\phi_{j}+e_{i j}$ in which each observed value is dependent upon a mean, plus an effect of the male cultivar, plus an effect of the female cultivar, and a residual error term. As there is no replication, the interaction mean square is used as an estimate of the residual error. The raw data from table 1 is first converted by the angular transformation and set out in a $6 \times 6$ two-way table, separately for $\mathrm{G} \times \mathrm{W}$ and $\mathrm{W} \times \mathrm{G}$ crosses (table 2). Tests for independence, for homogeneity of variances and for normality of the data, show that the conditions required to permit the use of anovar on the transformed data are adequately met.

\section{TABLE 3}

The main effects of the analysis of variance for the angular transformed data of the percentage green plastid output and the percentages of variegated embryos (table 2)

\begin{tabular}{|c|c|c|c|c|c|c|}
\hline \multirow[b]{2}{*}{ Source of variance } & \multicolumn{3}{|c|}{ Analysis of green plastids } & \multicolumn{3}{|c|}{ Analysis of variegated embryos } \\
\hline & d.f. & M.S. & $P$ & d.f. & M.S. & $\mathbf{P}$ \\
\hline \multicolumn{7}{|c|}{ (a) $G \times W$ crosses } \\
\hline Green females & 5 & $1426 \cdot 543$ & $\ll 0 \cdot 1 \%$ & 5 & $187 \cdot 459$ & $\ll 0 \cdot 1 \%$ \\
\hline White males & 5 & 51.797 & $1-0 \cdot 1 \%$ & 5 & $394 \cdot 795$ & $\ll 0 \cdot 1 \%$ \\
\hline Non-additivity & 1 & $70 \cdot 073$ & $5-1 \%$ & 1 & 1.737 & n.s. \\
\hline Interactions & 24 & $12 \cdot 538$ & - & 24 & $19 \cdot 989$ & - \\
\hline Total & 35 & - & - & 35 & - & - \\
\hline \multicolumn{7}{|c|}{ (b) $W \times G$ crosses } \\
\hline White females & 5 & $1143 \cdot 729$ & $\ll 0 \cdot 1 \%$ & 5 & $1263 \cdot 260$ & $\ll 0.1 \%$ \\
\hline Green males & 5 & $37 \cdot 760$ & $0 \cdot 5-0 \cdot 1 \%$ & 5 & $30 \cdot 642$ & n.s. \\
\hline Non-additivity & 1 & $0 \cdot 438$ & n.s. & 1 & $1 \cdot 186$ & n.s. \\
\hline Interactions & 24 & $7 \cdot 964$ & - & 24 & $18 \cdot 401$ & - \\
\hline Total & 35 & - & - & 35 & - & - \\
\hline
\end{tabular}

The main effects of the analysis are set out in table 3. The variance caused by differences between female cultivars is highly significant in both $\mathrm{G} \times \mathrm{W}$ and $\mathrm{W} \times \mathrm{G}$ crosses, and both for the analysis of green plastids and for variegated embryos. There are also significant effects of the male. The test for non-additivity shows that multiplicative effects are generally very small; an exception is the result for the analysis of green plastids after $\mathrm{G} \times \mathrm{W}$ crosses, but as this is only just significant at the 5 per cent level, and because it appears anomalous, it is given no further attention. The main effects are examined in more detail by breaking them down into orthogonal contrasts set out in table 4 . The choice of contrasts is kept the same throughout. For one degree of freedom I was most interested in comparing the type I and II plants. Within each of these groups inspection of the green plastid output (table 1) suggested that FS and FoS are closer to each other than either is to JCM, so the second orthogonal comparison is between FS and FoS, and the third between FS plus FoS and JCM. Similarly, the difference between LG and $\mathrm{MBC}$ is the fourth comparison and LG plus $\mathrm{MBC}$ are compared with DV for the fifth and last degree of freedom. It will be convenient to discuss the results step by step. 
Type I versus type II plants. The orthogonal contrasts confirm that the difference between the green plastid output for type I and type II females is highly significant $(\mathrm{P} \ll 0 \cdot 1$ per cent), both after $\mathrm{W} \times \mathrm{G}$ and $\mathrm{G} \times \mathrm{W}$ crosses. Other contrasts are somewhat ambiguous. The effect of white males shows a difference between type I and type II at the 0.5 per cent level, but the

TABLE 4

Orthogonal contrasts within the main effects of the percentage green plastid output and the percentages of variegated embryos (table 3)

Source of variance

Type I os against type II os FoS $q$ against FS $q$ FoS + FS os against JCM $ᄋ$ LG + against MBC ㅇ

$\mathrm{LG}+\mathrm{MBC}$ ㅇs against $\mathrm{DV}$ 우 Total (Green females)

Type I $\delta$ s against type II $\delta$ s FoS $\approx$ against FS $\approx$ FoS + FS os against JCM $\approx$ LG $\nsim$ against $\mathrm{MBC} \delta$

$\mathrm{LG}+\mathrm{MBC}$ ơs against $\mathrm{DV}$ ơ

Total (White males)

Error mean square

Type I qs against type II $q$ s FoS 9 against FS $q$

FoS + FS os against JCM 우 LG 우 against $\mathrm{MBC}$ 우

$\mathrm{LG}+\mathrm{MBC}$ 우 s against $\mathrm{DV}$ 우

Total (White females)

Type I $\delta$ s against type II $\delta$ s FoS of against FS $\delta$ $\mathrm{FoS}+\mathrm{FS}$ के against JCM $\delta$ LG o against MBC $\approx$

LG + MBC ð’s against DV む

Total (Green males)

Error mean square
Analysis of green plastids

$\overbrace{\text { d.f. M.S. } P} \overbrace{\text { d.f. } \quad \text { M.S. } \quad P}^{\text {An }}$

(a) $G \times W$ crosses

$\begin{array}{rccrc}6621.077 & \ll 0.1 \% & 1 & 40.960 & \text { n.s. } \\ 0.017 & \text { n.s. } & 1 & 585.203 & <0.1 \% \\ 2.873 & \text { n.s. } & 1 & 87.984 & 5-1 \% \\ 122.624 & 0.5-0 \cdot 1 \% & 1 & 195.375 & 0.5-0 \cdot 1 \% \\ 386.122 & <0.1 \% & 1 & 27.773 & \text { n.s. } \\ 7132.713 & - & 5 & 937.295 & - \\ & & & & \\ 163.073 & 0.5-0 \cdot 1 \% & 1 & 1860.484 & \ll 0 \cdot 1 \% \\ 0.195 & \text { n.s. } & 1 & 20.436 & \text { n.s. } \\ 0.156 & \text { n.s. } & 1 & 5 \cdot 093 & \text { n.s. } \\ 14.741 & \text { n.s. } & 1 & 34.476 & \text { n.s. } \\ 80.820 & 5-1 \% & 1 & 53.485 & \text { n.s. } \\ 258.985 & - & 5 & 1973.974 & - \\ 12.538 & - & 1 & 19.989 & -\end{array}$

(b) $W \times G$ crosses

$\begin{array}{rccrc}4130.204 & \ll 0.1 \% & 1 & 4347.204 & \ll 0.1 \% \\ 12.282 & \text { n.s. } & 1 & 7.776 & \text { n.s. } \\ 251.645 & <0.1 \% & 1 & 416.432 & <0.1 \% \\ 522.588 & \ll 0.1 \% & 1 & 46.295 & \text { n.s. } \\ 801.928 & \ll 0.1 \% & 1 & 1498.593 & \ll 0 \cdot 1 \% \\ 5718.647 & - & 5 & 6316.300 & - \\ & & & & \\ 20.703 & \text { n.s. } & 1 & 0.941 & \text { n.s. } \\ 11.682 & \text { n.s. } & 1 & 115.692 & 5-1 \% \\ 1.232 & \text { n.s. } & 1 & 1.323 & \text { n.s. } \\ 46.295 & 5-1 \% & 1 & 1.033 & \text { n.s. } \\ 108.889 & 0.5-0.1 \% & 1 & 34.222 & \text { n.s. } \\ 188.801 & - & 5 & 153.211 & - \\ 7.964 & - & 1 & 18.401 & -\end{array}$

green males show no difference. The result for variegated embryos is similar-white males are significantly different at the 0.1 per cent level but there is no difference between green males. This result might be indicative of an underlying heterogeneity among the mutant white plastids in contrast to the probable homogeneity of the green ones. Among females, the frequency of variegated embryos shows a huge difference after $\mathrm{W} \times \mathrm{G}$ crosses but none after $\mathrm{G} \times \mathrm{W}$ crosses.

Variation among type I plants. The contrast between LG and MBG shows that, as females, they are significantly different after $\mathrm{G} \times \mathrm{W}$ crosses $(\mathrm{P}<0.5$ per cent) and after $W \times G$ crosses $(P<0.1$ per cent $)$. As the genotype of the 
female is so important in controlling plastid inheritance, these results demonstrate that the two cultivars are distinct from one another. They, in turn, exhibit a highly significant difference from $D V(P<0 \cdot 1$ per cent $)$ after both $\mathrm{G} \times \mathrm{W}$ and $\mathrm{W} \times \mathrm{G}$ crosses. Hence all three cultivars have distinct genotypes each controlling plastid inheritance in such a way as to vary the output of green and white plastids. There are also differences in the frequencies of variegated embryos reinforcing the underlying variation between the three cultivars. When we look at the differences between these cultivars as males, the analysis suggests (table 4 ) that $\mathrm{LG}$ does not differ from $\mathrm{MBC}$ after $\mathrm{G} \times \mathrm{W}$ but does after $\mathrm{W} \times \mathrm{G}$ crosses. The difference is probably not real. The calculation of the error term for each observation indicates that the positive error value for the cross $\mathrm{LG} \mathrm{W} \times \mathrm{G} \mathrm{MBC}$ is the largest of the 36 crosses, and Grubbs' test (1969) shows that it is an outlier $(P<1$ per cent). This implies that the observed value is really too high. A missing value estimate (TilneyBassett, 1970a) suggests an angular value (table 2) that makes the mean value for $\mathrm{MBC}$ males no longer significantly different from LG males, whereas their combined and already significant difference with DV males is increased. It would also make LG and MBC females slightly closer together, but still not close enough to affect the statistical significance of their difference. There are no other outliers from the $\mathrm{W} \times \mathrm{G}$ crosses, and none from the $\mathrm{G} \times \mathrm{W}$ crosses for the green plastid output. In both $\mathrm{G} \times \mathrm{W}$ and $\mathrm{W} \times \mathrm{G}$ crosses DV male plastids are transmitted rather more successfully than all other cultivars. There is apparently no detectable difference between the cultivars as males in respect of the percentages of variegated embryos. Again, a check for outliers indicates that this statement must be treated with caution. The analysis of variegated embryos after $\mathrm{G} \times \mathrm{W}$ crosses reveals no outlier, but after $\mathrm{W} \times \mathrm{G}$ crosses the positive error value for the cross $\mathrm{MBC} W \times \mathrm{G} D V$ proves to be much too high $(\mathrm{P}<1$ per cent). A missing value estimate for this outlier suggests an angular value (table 2) that makes the difference between $\mathrm{DV}$ and LG plus $\mathrm{MBC}$ males just significant $(\mathrm{P}<2.5$ per cent $)$, but would not alter the contrasts on the female side.

The frequency of two outliers from among 144 observations is sufficiently low to be probable by chance alone and is not considered indicative of real aberrant behaviour in the two crosses.

Variation among type II plants. The contrast between FoS and FS, as females, shows no difference between them in respect of their green plastid output, either after $\mathrm{G} \times \mathrm{W}$ or after $\mathrm{W} \times \mathrm{G}$ crosses. There is also no difference between these two cultivars and JCM after $\mathrm{G} \times \mathrm{W}$ crosses, but a significant difference appears after $\mathrm{W} \times \mathrm{G}$ crosses $(\mathrm{P}<0 \cdot 1$ per cent $)$, in which JCM has a reduced output of green plastids. When variegated embryos are compared FoS and FS are separated after $\mathrm{G} \times \mathrm{W}$ crosses $(\mathrm{P}<0.1$ per cent). It therefore seems highly probable that these three type II cultivars are not identical, but have small genotypic differences altering the precise output of green and white plastids and the degree of mixing. When used as males, there is no convincing difference with any probability value below the 1 per cent level.

\section{Discussion}

The analysis of reciprocal crosses clearly shows that the principles developed for $\mathrm{G} \times \mathrm{W}$ crosses hold equally for $\mathrm{W} \times \mathrm{G}$ crosses. The wide range 
of reciprocal crosses further shows that the considerable difference between $\mathrm{G} \times \mathrm{W}$ and $\mathrm{W} \times \mathrm{G}$ crosses, found even after isogenic crosses, may be satisfactorily described when we take into account both the maternal versus paternal effect, and the normal versus mutant effect. Among type I plants, the $\mathrm{G} \times \mathrm{W}$ crosses exhibit a strong maternal predominance which is greatly weakened, but not completely reversed, in the reciprocal $\mathrm{W} \times \mathrm{G}$ crosses, and hence the green plastid frequency falls. Among the type II plants, the $\mathrm{G} \times \mathrm{W}$ crosses exhibit an almost equally male and female inheritance which is uniformly shifted to a strong paternal predominance in the reciprocal $\mathrm{W} \times \mathrm{G}$ crosses, and hence the green plastid frequency rises.

The analysis of variance has shown that besides the major genotypic and phenotypic differences between types I and II, there is also a highly significant heterogeneity within the types such that no two of the six cultivars seem identical. Among the type I plants, the genotypic differences are reflected in their varying strengths as females. After $\mathrm{G} \times \mathrm{W}$ crosses, the segregation pattern of DV is predominantly maternal, but switches to predominantly paternal after $\mathrm{W} \times \mathrm{G}$ crosses. Nevertheless the paternal transmission is not so favourable to the green plastids as the maternal. With LG the inheritance pattern is visibly shifted towards the maternal influence. Finally, MBG is such a strong female that it is the only cultivar in which there are no white embryos after all six $\mathrm{G} \times \mathrm{W}$ crosses. Moreover, the maternal advantage of $\mathrm{MBC}$ is strong enough to overcome the disadvantage associated with white plastids so that, for the first time, there are more white than green embryos after $\mathrm{W} \times \mathrm{G}$ crosses. $\mathrm{MBC}$ is therefore the only cultivar in which, in spite of the advantage of green plastids, the inheritance manages to be predominantly maternal after both reciprocal crosses; with the other five cultivars plastid transmission is predominantly paternal after $\mathrm{W} \times \mathrm{G}$ crosses. Among type II plants, JGM is more maternal, or rather less paternal, than the other two because the green plastid output is relatively depressed after $\mathrm{W} \times \mathrm{G}$ crosses. It is therefore possible to arrange the six cultivars in order of decreasing maternal strength as follows: $\mathrm{MBC}>\mathrm{LG}>\mathrm{DV}>\mathrm{JCM}>\mathrm{FS}=\mathrm{FoS}$. It is interesting to note that the ratio of the $G: W$ plastid output averages over 20: l with green $\mathrm{MBC}$ as female compared with 1:1 with green FS. Since the males are the same in both cases the input by the male is presumably constant. This means either that the female input of plastids must vary by 20 -fold or, as is much more likely, there is little or no relationship between the input and output of plastids.

The behaviour of these cultivars fully substantiates the existence of genes located in the female parent which control the output of the male and female plastids. The $\operatorname{Pr}$ gene operates a major switch shunting plastid transmission into a maternal direction in the type I, homozygous plants, or into a paternal direction in the type II, heterozygous plants. How far the inheritance is pushed in one direction or another is then determined by other independent genes. A multiple allele hypothesis is unattractive owing to the behaviour of hybrids between DV and FS. When 62 sister hybrids were studied (Tilney-Bassett, 1973) they fell into the two classes-type I and type II, but within each class there was a comparable variation in segregation pattern and green plastid output as is represented by the six cultivars. Assuming that most of this variation was also genotypic, it could scarcely be accounted for by the limited number of alleles available at one locus from the two parents.

Evidence for genetic variation is also demonstrated by the analysis of 
variegated embryos. After $\mathrm{G} \times \mathrm{W}$ crosses, the $\mathrm{G}: \mathrm{W}$ plastid ratio is practically identical for FoS and FS, yet for everyone of the crosses with six different males FoS has a higher proportion of variegated progeny than FS. It seems that with the same plastid ratio the extent to which the plastids mix, or replicate together, is dependent on the female cultivar and is under genetic control.

A final example of the evidence for varying genotypes controlling aspects of plastid inheritance is the significant effect of $\mathrm{DV}$ as a male after $\mathrm{G} \times \mathrm{W}$ crosses and, even more so, after $\mathrm{W} \times \mathrm{G}$ crosses. After $\mathrm{G} \times \mathrm{W}$ crosses, the white plastids of DV are transmitted more successfully than those of any other cultivar as male, similarly the green plastids are the most successful after $\mathrm{W} \times \mathrm{G}$ crosses. Another male effect is shown by the greater frequency of variegated embryos after all $\mathrm{G} \times \mathrm{W}$ crosses with type I males compared with type II males. The absence of any significant difference between the males after $\mathrm{W} \times \mathrm{G}$ crosses, suggests that the highly significant difference after $\mathrm{G} \times \mathrm{W}$ crosses might be caused by genetically different mutant plastids. As we have seen, it is usual for nuclear differences between type I and II to have an effect on both normal and mutant plastids and not differentiate between them. In addition electron-microscope studies show that FoS and FS are structurally similar but differ in their developmental capabilities from the mutant plastids of LG and MBC (Khera, 1975), so they might differ in other ways as well. The major importance of the nuclear genotype for controlling plastid inheritance in Pelargonium contrasts with the results from Oenothera in which Schötz $(1974,1975)$ found that variations in the nuclear background are less significant than the difference between sexes and between the inherent properties of the plastids (see also Tilney-Bassett, 1975).

In a previous paper (Tilney-Bassett, 1974b) I suggested, from the results of $\mathrm{G} \times \mathrm{W}$ crosses, that there may be a mechanism that seeks to recognise and remove abnormal plastids and plastid DNA irrespective of the parental source. The exploration of $\mathrm{W} \times \mathrm{G}$ crosses, and the extension of $\mathrm{G} \times \mathrm{W}$ crosses, now indicates that white plastids are indeed less successful than their green counterparts in all six cultivars. Nevertheless, the idea that some genotypes are particularly efficient at eliminating mutant plastids is not supported because, generally speaking, the behaviour of white plastids follows that of the green plastids. Thus the cultivar with the best green plastids, as male, has the best white plastids as male. Similarly, the cultivar with the most successful green plastids, as female, also has the most successful white plastids as female. Hence, a more appropriate contention is that the genotypic variation between cultivars controls the ability to eliminate male plastids, rather than specifically mutant ones, although, as we have seen, the degree of success is also dependent on whether the plastids are normal or mutant. We therefore find that the green $\mathrm{MBC}$ is the cultivar most able to eliminate mutant male plastids after $\mathrm{G} \times \mathrm{W}$ crosses, but the very success of this genotype makes it the most vulnerable after the reciprocal $\mathrm{W} \times \mathrm{G}$ crosses. Because it is the best at eliminating male plastids it cannot avoid being least able to rid itself of white plastids from the female side. Clearly if, through selection, the condition represented by $\mathrm{MBC}$ were to be extended to the limit, we should obtain plants with the typical condition of purely maternal inheritance in which the complete success of the female in eliminating the male plastids would result in the protection of the normal female as all progeny would be green after $\mathrm{G} \times \mathrm{W}$ crosses; this situation already exists in 
many individuals (Tilney-Bassett, 1973, 1974b). On the other hand, it would be disastrous for the progeny of $\mathrm{W} \times \mathrm{G}$ crosses as all would be white and die.

Precisely how the genetic control of plastid inheritance operates is still unknown. Sager (1975) has suggested that the female plastid DNA in Pelargonium might be protected by modification, and the unmodified male plastid DNA destroyed by a site-specific restriction enzyme, in the same manner as had been proposed for the control of plastid inheritance in Chlamydomonas (Sager and Ramanis, 1973). Nevertheless, I still prefer to think in terms of determining plastid inheritance by controlling plastid replication (Tilney-Bassett, 1970b). It is my view that of the two types of plastid, frequently only one is replicated and that within a given zygote each has a specific probability of replication first, and the first to replicate may effectively inhibit the replication of the other. The genetic controls might enable a differential replication to take place without necessarily destroying the non-replicating plastid. This would have the advantage of numerically reducing the stationary, non-replicating plastid, but would still permit a few to sort-out into the embryo cells perfectly capable of dividing again as soon as the restriction was lifted. Assuming, as shown for Oenothera (Meyer and Stubbe, 1974), that the egg contributes more plastids to the zygote than the male and that plastid replication does take place, it would be easier to select in the direction of maternal inheritance although paternal would also be possible. Some destruction of the inhibited plastids and plastid DNA would aid the establishment of the replicating plastid, but complete destruction does not seem to be a part of the Pelargonium system in which some biparental, variegated embryos are almost always present, other than for the most extreme crosses. The concept of selective replication or destruction of mitochondrial DNA has also been developed to explain the results of yeast crosses (Birky, 1975). The model proposed for the Chlamydomonas data, which Gillham et al. (1974) have put forward is very similar. They suggest that the chloroplast DNA molecules from the two parents have to compete for a fixed and limited number of membrane attachment sites required for replication and segregation. These sites are occupied preferentially by the maternal genomes, but occasionally a paternal genome gains access to a site and a biparental zygote results, and very rarely there is a change in the specificity leading to a reversal of the attachment sites in favour of the paternal genomes. They too consider that immediate destruction of unattached genomes is not necessary as diluting-out in the successive cell divisions would be adequate. It will be interesting to see, as further progress is made, whether the similarities between the different organisms really do reflect a common mechanism or whether the evolutionary process has solved the problem of controlling plastid and mitochondrial inheritance in a variety of ways.

Acknowledgments. - I wish to thank Miss Jill Locke-Edmunds for her valuable help with the crossing programme.

\section{REFERENCES}

BIRKY, c. w., JR. 1975. Zygote heterogeneity and uniparental inheritance of mitochondrial genes in yeast. Molec. gen. Genet., 141, 41-58. 
GIllham, N. W., Boynton, J. E., AND LEE, R. w. 1974. Segregation and recombination of non-mendelian genes in Chlamydomonas. In XIII International Congress of Genetics. Genetics, 73, 439-457.

GRUBBs, F. E. 1969. Procedure for detecting outlying observations in samples. Technometrics, 11, 1-21.

khera, P. K. 1975. Plastid development in zonal pelargoniums. Ph.D. Thesis, University College of Swansea, Wales.

MEYER, B., AND STUBBE, w. 1974. Das Zahlenverhältnis von mütterlichen und väterlichen Plastiden in den Zygoten von Oenothera erythrosepala Borbas (syn. Oe. lamarckiana). Ber. Deutsch. Bot. Ges., 87, 29-38.

SAGER, R. 1975. Patterns of inheritance of organelle genomes: molecular basis and evolutionary significance. In Genetics and Biogenesis of Mitochondria and Chloroplasts, pp. 252267. Eds. C. W. Birky, Jr., P. S. Perlman, and T. J. Byers. The Ohio State University Press, Columbus.

SAGER, R., AND RAMANIS, z. 1973. The mechanism of maternal inheritance in Chlamydomonas: biochemical and genetic studies. Theoret. Appl. Genet., 43, $101-108$.

sснӧтz, F. 1974. Untersuchungen über die Plastidenkonkurrenz bei Oenothera IV. Der Einfluss des Genoms auf die Durchsetzungsfähigkeit der Plastiden. Biologisches Zentralblatt, 93, 41-64.

schötz, F. 1975. Untersuchungen über die Plastidenkonkurrenz bei Oenothera V. Die Stabilität der Konkurrenzfähigkeit bei Verwendung verschiedenartiger mutierter Testplastiden. Biologisches Zentralblatt, 94, 17-26.

TILNEY-BASSETT, R. A. E. 1970a. Genetics and plastid physiology in Pelargonium. III. Effect of cultivar and plastids on fertilization and embryo survival. Heredity, 25, 89-103.

TILnEy-BAsSETt, R. A. E. $1970 b$. The control of plastid inheritance in Pelargonium. Genet. Res. Camb., 16, 49-61.

TILNEY-BASSETT, R. A. E. 1973. The control of plastid inheritance in Pelargonium. II. Heredity, 30, 1-13.

TILNEY-BASSETT, R. A. E. 1974a. A search for the rare type II $(\mathrm{G}>\mathrm{V}<\mathrm{W})$ plastid segregation pattern among cultivars of Pelargonium $\times$ Hortorum Bailey. Ann. Bot., 38, 333-335.

TILNEY-BASSETT, R. A. E. 1974b. The control of plastid inheritance in Pelargonium. III. Heredity, 33, 353-360.

TILNEY-BASSETT, R. A. E. 1975. Genetics of variegated plants. In Genetics and Biogenesis of Mitochondria and Chloroplasts, pp. 268-308. Eds. C. W. Birky, Jr., P. S. Perlman, and T. J. Byers. The Ohio State University Press, Columbus. 